\title{
Are Electronically Developed Countries Gaining More from ICT Investments?
}

\author{
George F. Tsachtsiris ${ }^{1}$, Anastasios I. Magoutas ${ }^{2,1}$ and Giannis T. Tsoulfas ${ }^{3,1}$ \\ ${ }^{1}$ Hellenic Open University, School of Social Sciences, Greece \\ ${ }^{2}$ University of Athens, General Department, Greece \\ ${ }^{3}$ Agricultural University of Athens, General Department, Greece
}

\begin{tabular}{|c|c|}
\hline ARTICLE INFO & ABSTRACT \\
\hline $\begin{array}{l}\text { Keywords: } \\
\text { ICT } \\
\text { Economic Growth } \\
\text { Panel Data } \\
\text { Organizational Issues } \\
\text { Production Function }\end{array}$ & $\begin{array}{l}\text { This paper examines whether electronically developed countries are } \\
\text { gaining more from investments in information and communication } \\
\text { technology (ICT) products. Previous research in the field has } \\
\text { extensively used the GDP per capita as an index for country } \\
\text { categorization into developed, emerging and developing. Instead, we } \\
\text { make use of the UN's electronic government development index } \\
\text { (EGDI) in order to construct two groups of countries based on their } \\
\text { level of electronic development for the period 2007-2016. We use } \\
\text { panel data regressions to estimate an augmented Cobb-Douglas } \\
\text { production function for each of these two groups as well as the } \\
\text { combined sample of all countries. The results indicate that ICT output } \\
\text { elasticities are positive and statistically significant for both group of } \\
\text { countries, with electronically developed countries having an edge over } \\
\text { less developed. Moreover, the hypothesis of equal ICT elasticities } \\
\text { between the two groups could not be rejected, suggesting that } \\
\text { electronically developed countries do not exhibit excessive returns } \\
\text { from ICT investments. }\end{array}$ \\
\hline
\end{tabular}

\section{Introduction}

It is undisputed that productivity and economic growth pave the way to a nation's well-being and prosperity. As a result, the driving forces behind economic growth are always at the forefront. During the last three decades the role of ICT investments on productivity has been extensively studied (Stiroh, 2005; Draca et al., 2006; Cardona et al., 2013). The truth is that the perception about this role has important implications shaping the investment and strategic policies of nations. For instance, the European Commission has launched the EU "Digital Single Market" strategy aiming among others at improving connectivity and access, infrastructure and inclusive digital society ${ }^{1}$. In the US after the 2007 economic crisis the recovery $\mathrm{act}^{2}$ was announced as a stimulus for the economy to rebound with investments in ICT infrastructure in the order of $\$ 10.5 \mathrm{bn}^{3}$.

The task of measuring the impact of ICT is difficult in itself. This happens not only because by ICTs we mean a multitude of products (PCs, smartphones, software, network devices etc.) and services (internet service providers, mobile services etc.) that change rapidly over time, but also because the term "impact" is difficult to determine as it is multifaceted (economic,

\footnotetext{
${ }^{1}$ See https://ec.europa.eu/digital-single-market/en

${ }^{2}$ American Recovery and Reinvestment Act of 2009

${ }^{3}$ See https://en.wikipedia.org/wiki/American_Recovery_and_Reinvestment_Act_of_2009
} 
social, environmental). To make matters even more complex many ICTs are regarded as General Purpose Technologies (GPT) and as such have indirect effects that lag in time, with the lag period being unknown (Cardona et al., 2013). On top of that, the impact varies depending on the methodological approach, the secondary data used and the period under examination.

In the literature, several studies examine whether the impact of ICT investments on economic growth is greater in developed countries rather than in developing and/or emerging ones. The rational is whether developed countries exhibit higher "absorptive capacities"4 or whether developing countries can "leapfrog" the accumulated capabilities and infrastructure of developed countries through ICT investments (Steinmueller, 2001; Kneller, 2005). The impact is usually measured through econometric regressions at the macro-level by comparing output elasticities and the results reveal extensive variability. For instance, early studies such as Dewan \& Kraemer (2000), Pohjola (2002) and Lee (2005) find no significant effect between ICT investments and economic growth of developing countries. Yousefi (2011) reports insignificant ICT elasticity for lower-middle income group of countries, however he finds the highest ICT elasticity for the upper-middle income group. It should be noticed that the estimated coefficient of 0.35 , for the upper-middle income group, is one of the highest reported in the literature (see for comparison the review paper of Cardona et al., 2013, Table 5). Dedrick et al. (2013) and Niebel (2018) conclude that both developed and developing countries exhibit a positive relationship between ICT investments and productivity growth, with the ICT coefficient in developing countries being slightly larger than in developed ones ${ }^{6}$. Similar results are reported in Dimelis and Papaioannou (2010) showing a positive and significant effect for both groups of countries, with the developing countries gaining more from ICT than developed ones.

The contribution of the current paper is threefold. First of all, instead of segregating countries based on their GDP per capita, we use the Electronic Government Development Index (EGDI) published by the UN, which ranks countries based on their level of electronic development. According to $\mathrm{UN}^{7}$ the impact of ICT investments is likely to be influenced by the development of a country (ICT infrastructure, government ICT policy and level of education and skills). Our primary objective is to investigate whether electronically developed countries are gaining more from ICT investments. Secondly, we use as source of secondary data the Conference Board Total Economy Database (TED) ${ }^{8}$, which makes use of capital services that are more appropriate to measure ICT investments, and as a result more accurate results are expected. Additionally, taking into consideration that most of the studies in the field make use of capital stocks, a comparison of results is feasible. Finally, we try to draw conclusions from an ICT policy-making point of view.

The remainder of the paper is organized as follows. In the second section the econometric model used is stated, the procedure for the country group selection based on the EGD index is described and the conducted regression diagnostic tests to decide upon the choice of estimator are explained. Section three lays out econometric results and offers a discussion on the key findings along with comparisons across literature. Finally, in the fourth section we summarize the main findings.

\footnotetext{
${ }^{4}$ The ability to apply new technologies

5 The ability to skip several initial phases of ICT development as the way has been already paved by developed countries

${ }^{6}$ Dedrick et al. (2013) examine only upper-income developing countries, whereas Niebel segregates countries into developed, emerging and developing

${ }^{7}$ Measuring the Impacts of ICT for Development, See https://unctad.org/en/Docs/dtlstict2011d1_en.pdf

${ }^{8}$ See https://www.conference-board.org/data/economydatabase/
} 


\section{Methodology}

As stated in the introduction, the EGDI published by the UN is used to segregate countries based on their level of electronic development, which can be viewed also as a measure of their ability to better use ICT investments. The benefits emerging from e-government are well understood: improvement of information quality, time and cost reduction in administrative processes, better training capabilities and user satisfaction. Ultimately, we believe that if there is a correlation between organizational issues and ICT investments at the macro-level, then the criterion for country segregation based on EGDI could serve as a better way to examine whether electronically developed countries gain more from ICT investments. To put it differently, to examine whether an upward bias is reflected in the estimated ICT output elasticity of electronically developed countries.

The EGDI score is calculated as a weighted average of three indices: scope and quality of online services (Online Services Index-OSI), telecommunications infrastructure index (TII) and human capital index (HCI) (UN, 2019). UN announces results, usually, on a biennial basis starting from 2003 for a total of 193 countries. For the purposes of our study we calculated the average score for every country for the period 2007-2016 and selected two groups of countries. The High Ranking (HR) countries are the top 27 performers, whereas the Middle Ranking (MR) ones are 25 countries chosen from the middle tier of the sorted list. It should be mentioned, however, that not all countries listed in UN have available data in the TED database and additionally not all countries in the TED database report ICT capital investments. As a result, the choice of MR countries comes with rather limited variability. The countries for each group are shown in Tab.1 below.

Table 1.

List of Selected Countries Along with Averages of Indices Values for the Period 2007-2016

\begin{tabular}{|c|c|c|c|c|c|}
\hline & High Ranking & Avg score & & Middle Ranking & Avg score \\
\hline 1 & Australia & 5.9 & 1 & Bolivia & 91.4 \\
\hline 2 & Austria & 18.9 & 2 & China & 68.3 \\
\hline 3 & Belgium & 20.6 & 3 & Costa Rica & 65.4 \\
\hline 4 & Canada & 8.4 & 4 & Dominican Republic & 83.1 \\
\hline 5 & Denmark & 5.8 & 5 & Ecuador & 85.9 \\
\hline 6 & Estonia & 17 & 6 & Egypt & 104.4 \\
\hline 7 & Finland & 10.8 & 7 & India & 105.3 \\
\hline 8 & France & 13.1 & 8 & Indonesia & 98.1 \\
\hline 9 & Great Britain & 4.8 & 9 & Iran & 105.1 \\
\hline 10 & Germany & 15.3 & 10 & Jamaica & 85.3 \\
\hline 11 & Iceland & 19.4 & 11 & Kuwait & 65.5 \\
\hline 12 & Ireland & 22.3 & 12 & Morocco & 120 \\
\hline 13 & Israel & 20.9 & 13 & Peru & 64.4 \\
\hline 14 & Italy & 26.6 & 14 & Philippines & 64.9 \\
\hline 15 & Japan & 14.1 & 15 & Qatar & 59.3 \\
\hline 16 & Luxembourg & 23.1 & 16 & Saudi Arabia & 65.5 \\
\hline 17 & Malta & 29.1 & 17 & Serbia & 81.1 \\
\hline 18 & Netherlands & 7.3 & 18 & South Africa & 73.3 \\
\hline 19 & New Zealand & 12.8 & 19 & Sri Lanka & 94.3 \\
\hline 20 & Norway & 9.4 & 20 & Thailand & 70.4 \\
\hline 21 & Republic of Korea & 4.4 & 21 & Tunisia & 98.6 \\
\hline 22 & Singapore & 9.8 & 22 & Turkey & 66.3 \\
\hline 23 & Slovenia & 27.9 & 23 & Ukraine & 57.4 \\
\hline 24 & Spain & 22.9 & 24 & Venezuela & 70.5 \\
\hline
\end{tabular}




\begin{tabular}{cllllll}
\hline & High Ranking & Avg score & & & Middle Ranking & Avg score \\
\cline { 1 - 1 } 25 & Sweden & 6.1 & & & & \\
26 & Switzerland & 17.9 & & & & \\
27 & USA & 4.1 & & & & \\
\hline
\end{tabular}

Note. Source: UN EGDI (2019)

\subsection{Econometric Model}

To measure the effect of ICT investments on economic growth we use the augmented CobbDouglas production function to run panel data regressions. The production function is "augmented" in the sense that the capital input is decomposed into ICT and non-ICT capital inputs, in order to study the impact of the former. The equation used for the production function regressions is the following:

$$
\Delta \ln Y_{i t}=\Delta \operatorname{lnTFP} P_{i}+\varepsilon_{\text {ICT }} \Delta \ln K_{i t}^{\mathrm{ICT}}+\varepsilon_{\text {NICT }} \Delta \ln K_{i t}^{\mathrm{NICT}}+\varepsilon_{\mathrm{L}} \Delta \ln \mathrm{L}_{\mathrm{it}}+\delta_{t}+\mathrm{e}_{\mathrm{it}}
$$

where $\Delta \ln Y_{\text {it }}$ is the growth rate of GDP, $\Delta \ln K_{i t}{ }^{\text {ICT }}$ and $\Delta \ln K_{i t}{ }^{\text {NICT }}$ are the growth rates of ICT and non-ICT capital services, $\Delta \ln L_{i t}$ is the growth rate of labor (quantity and quality) services, whereas the indices $i$ and $t$ represent the country and time respectively. The term $\triangle \operatorname{lnTFP} i$ is the total factor productivity (country dummy variable in the fixed effects model), $\mathrm{e}_{\mathrm{it}}$ is the idiosyncratic error, whereas $\varepsilon_{\mathrm{ICT}}$, हNICT and $\varepsilon_{\mathrm{L}}$ are the elasticities of the input factors. The time dummies $\delta_{\mathrm{t}}$ control for time-specific effects, such as common financial shocks (for instance EU economic crisis during 2009-2010) or common trends.

To test for the equality of coefficients of the two groups, Eq. 1 is extended to include a dummy variable HR ( 1 for a country belonging to HR group and 0 otherwise) and interaction terms between each of the regressors and the dummy variable.

$$
\begin{gathered}
\Delta \ln \mathrm{Y}_{\mathrm{it}}=\Delta \operatorname{lnTFP}_{\mathrm{i}}+\alpha H R+\beta H R \Delta \operatorname{lnK}_{\mathrm{it}}^{\mathrm{ICT}}+\gamma H R \Delta \operatorname{lnK}_{\mathrm{it}}^{\mathrm{NICT}}+\delta H R \Delta \operatorname{lnL}_{\mathrm{it}}+\varepsilon_{\mathrm{ICT}} \Delta \operatorname{lnK}_{\mathrm{it}}^{\mathrm{ICT}}+\varepsilon_{\mathrm{NICT}} \Delta \operatorname{lnK}_{\mathrm{it}}^{\mathrm{NICT}} \\
+\varepsilon_{\mathrm{L}} \Delta \ln \mathrm{L}_{\mathrm{it}}+\delta_{t}+\mathrm{e}_{\mathrm{it}}
\end{gathered}
$$

In our case we are more interested in the $\mathrm{HR} \Delta \ln \mathrm{K}_{\mathrm{it}}{ }^{\mathrm{ICT}}$ interaction term, which accounts for the change in the slope of ICT capital investments between the two groups. In order to test the equality of ICT coefficients between the two country groups (HR and MR), we examine the statistical significance of the interaction term HR $\Delta \ln \mathrm{K}_{\mathrm{it}}{ }^{\mathrm{ICT}}$.

\subsection{Data}

The secondary data for the analysis is derived from the Conference Board TED, which provides data in the domains of growth accounting and productivity at the country level, facilitating reliable international comparisons. Data from 123 countries since 1950 are aggregated from different reliable sources such as the Organization for Economic Cooperation and Development (OECD), International Monetary Fund (IMF), the World Bank, the International Labour Organization (ILO) and national account statistics.

According to OECD (2009) capital can be measured either as a storage of wealth or as a source of capital services. Although these are two distinct aspects of measurement, there is a clear link between them since the age-price profile of an asset hangs together with its ageefficiency profile. The point is that the selection between net capital stock and productive capital stock as the most appropriate measure depends on the context of use. The TED database uses capital services instead of capital stocks, which are more suitable for growth accounting, since the price of an asset is almost never proportional to its ability to produce goods and services. Capital services reflect how much ICT assets produce each period instead of tracking their market value. Moreover, the use of capital services is more consistent with the other variables of the production function which express flows.

\subsection{Regression diagnostic tests}

The choice of estimator (Fixed or Random Effects) can be made based on whether we can "treat our sample as a random sample from a large population" (Wooldridge, 2015). Since 
both samples (country groups) are not exhaustive of the population, it makes sense to consider random effects. However, there are two caveats: firstly, the HR sample is not random and secondly the population is not considered large ${ }^{9}$. Consequently, we carried out four diagnostic tests to decide upon the choice of estimator. The F-test was used to compare the pooled OLS model (restricted) with the fixed effects model (unrestricted), to examine whether fixed effects (country-specific in our case) are jointly significant. A second F-test was conducted between the fixed effects model (restricted) and the same model with a full set of year dummies (unrestricted) to conclude whether year dummy variables are jointly significant and hence time fixed effects should be included in the model. For the existence of random effects, the Breusch-Pagan Lagrange Multiplier test was conducted. Finally, in case where both fixed and random effects are detected, we used a Hausman test to choose between the two. The results are shown and discussed in section 3.

To test for homoskedasticity and serial correlation the Breusch - Pagan and the BreuschGodfrey tests were used respectively. Although the presence of heteroskedasticity in the errors does not cause bias or inconsistency in estimators, it causes bias in variance and problems in inference. To correct for the bias, robust estimations of the standard errors are computed and presented in the results. To this end we used the Newey \& West robust covariance matrix estimator, which is robust to serial correlation and heteroskedasticity, but comes with the assumption of the correlation dying out as the distance between observations increases (Millo, 2017).

\section{Results and Discussion}

The results of the regression diagnostic tests are depicted in Tab.2 for the three data samples, the HR and MR groups and the combination of the two. For the HR group sample, the null hypotheses of non-significant country-specific effects $(\mathrm{p}=0.78)$ and random effects $(\mathrm{p}=0.25)$ cannot be rejected and as a result the pooled OLS is selected. On the contrary, for the other two samples both hypotheses are rejected and we used a Hausman specification test. For both cases the Hausman test could not be rejected and the RE estimator was chosen as more efficient. Nevertheless, the results of the FE estimator are also presented for reasons of comparison.

The F-test of non-significant year dummies was rejected for all three samples $(\mathrm{p}<0.01)$. The 2008 and 2009 year dummies are individually significant in all samples and it is attributed to the global economic crisis that started in 2007 in US and affected all countries with a time lag. For the HR and the combined sample, years 2012 and 2013 are as well individually significant, whereas the rest of the year dummies are jointly significant at $5 \%$. For this reason, we decided to include in the model a full set of year dummies.

Table 2

Regression Diagnostic Tests for the Production Function

\begin{tabular}{|c|c|c|c|c|}
\hline \multicolumn{2}{|r|}{ Null Hypothesis } & \multicolumn{3}{|c|}{ Test Statistics (p-value) } \\
\hline & & High Ranking & Middle Ranking & Combined \\
\hline (1) & $\begin{array}{l}\text { Country-specific effects are not significant(F- } \\
\text { test) }\end{array}$ & $\begin{array}{l}F=0.77 \\
(p=0.78)\end{array}$ & $\begin{array}{l}F=2.08 \\
(p=0.03)\end{array}$ & $\begin{array}{l}F=1.55 \\
(p=0.01)\end{array}$ \\
\hline (2) & Year dummies are not significant (F-test) & $\begin{array}{l}F=22.22 \\
(p<0.01)\end{array}$ & $\begin{array}{l}F=4.39 \\
(p<0.01)\end{array}$ & $\begin{array}{l}F=16.73 \\
(p<0.01)\end{array}$ \\
\hline (3) & $\begin{array}{l}\text { Random effects are not significant (BP } \\
\text { LM,test) }\end{array}$ & $\begin{array}{l}\chi^{2}=1.32 \\
(\mathrm{p}=0.25)\end{array}$ & $\begin{array}{l}\chi^{2}=8.21 \\
(p<0.01)\end{array}$ & $\begin{array}{c}\chi^{2}=3.98 \\
(p=0.046)\end{array}$ \\
\hline (4) & Hausman test (FE vs RE) & -- & $\begin{array}{l}\chi^{2}=2.37 \\
(p=0.5)\end{array}$ & $\begin{array}{l}\chi^{2}=7.65 \\
(\mathrm{p}=0.265)\end{array}$ \\
\hline
\end{tabular}

The regression results are depicted in Tab.3. For both groups all coefficients have a positive relationship with the GDP growth rate and are statistically significant, with the exception of

\footnotetext{
${ }^{9}$ From the total of 193 countries of UN, TED provides data for 123 countries not all of the them reporting ICT investments
} 
total labor services for middle ranking countries. A possible explanation could be the fact that in developing countries the number of employees instead of total hours worked is reported (also commented in Niebel, 2018).

ICT elasticity is statistically significant at $5 \%$ for both groups of countries. For the HR group the coefficient is 0.085 , whereas for the MR group it is 0.071 . The results are interpreted as follows: a 10\% increase in the growth rate of ICT capital services would result, on average, in $0.85 \%$ increase in the GDP growth rate of HR countries and $0.71 \%$ increase in MR countries. By comparing the results with the literature, we can make the following remarks: contrary to Dewan \& Kraemer (2000), Pohjola (2002) and Lee (2005) we find a positive significant relationship between ICT investments and economic growth for the MR group sample. It should be mentioned that the majority of the countries in this group are either developing or emerging and thus such a comparison is meaningfu $1^{10}$. The ICT elasticity of the electronically developed countries is higher than the one of the less developed, which is against the findings of a higher ICT elasticity of middle-upper income countries of Yousefi (2011) and Dedrick et al. (2013). Finally, the regression estimates of Tab.3 are in line with the results reported in Niebel (2018, Tab. 4.3) for developed and developing/emerging countries, using the same database with a data sample covering the period 1995-2010.

According to the last column of the combined sample in Tab. 3, the interaction term $\mathrm{HR} \Delta \ln \mathrm{K}_{\mathrm{it}}{ }^{\mathrm{ICT}}$, accounting for the difference between the ICT elasticities of the two groups, is statistically insignificant ( $\mathrm{p}=0.71$ ). Based on our empirical results there is evidence that both electronically developed countries and countries that are lagging behind according to EGDI ranking are enjoying comparable economic growth from ICT investments. In other words, countries that are more developed with respect to human capital, telecommunication infrastructures and online services do not appear to be gaining more from ICT investments. For instance, Pohjola (2001) attributes the statistically insignificant contribution of ICT investments of developing countries to the fact that that they lack in the accumulation of infrastructure and human capital. Such a hypothesis does not seem to be supported by our results.

Table 3

Estimation of the Production function with Dependent Variable: $\Delta \ln G D P$, for the period 2007-2016, for the Three Samples HR, MR and Combined

\begin{tabular}{|c|c|c|c|c|c|}
\hline & \multirow{2}{*}{$\begin{array}{c}\text { High Ranking } \\
\text { OLS }\end{array}$} & \multicolumn{2}{|c|}{ Middle Ranking } & \multicolumn{2}{|c|}{ Combined } \\
\hline & & $\mathrm{FE}$ & RE & $\mathrm{FE}$ & $\mathrm{RE}$ \\
\hline$\Delta \ln \mathrm{K}_{\mathrm{ICT}}$ & $0.085^{*}$ & $0.077 *$ & $0.071^{*}$ & $0.075^{*}$ & $0.071 *$ \\
\hline & $(0.040)$ & $(0.033)$ & $(0.032)$ & $(0.033)$ & $(0.032)$ \\
\hline$\Delta \ln K_{\mathrm{NICT}}$ & $0.327^{*}$ & $0.739 * * *$ & $0.649 * * *$ & $0.804 * * *$ & $0.67 * * *$ \\
\hline & $(0.128)$ & $(0.176)$ & $(0.097)$ & $(0.033)$ & $(0.088)$ \\
\hline$\Delta \operatorname{lnL}$ & $\begin{array}{c}0.496 * * * \\
(0.093)\end{array}$ & $\begin{array}{c}0.057 \\
(0.056)\end{array}$ & $\begin{array}{c}0.057 \\
(0.042)\end{array}$ & $\begin{array}{c}0.058 \\
(0.058)\end{array}$ & $\begin{array}{c}0.063 \\
(0.042)\end{array}$ \\
\hline $\begin{array}{l}\text { Time } \\
\text { Dummies }\end{array}$ & yes & yes & yes & yes & yes \\
\hline $\mathrm{HR} \Delta \ln \mathrm{K}_{\mathrm{ICT}}$ & -- & & -- & $\begin{array}{l}-0.038 \\
(0.06) \\
\end{array}$ & $\begin{array}{c}-0.021 \\
(0.055)\end{array}$ \\
\hline $\begin{array}{l}\mathrm{HR} \\
\Delta \ln \mathrm{K}_{\mathrm{NICT}}\end{array}$ & -- & & -- & $\begin{array}{l}-0.527 * \\
(0.238)\end{array}$ & $\begin{array}{l}-0.387^{*} \\
(0.174)\end{array}$ \\
\hline HR L & & & & $\begin{array}{l}0.51 * * * \\
(0.115)\end{array}$ & $\begin{array}{c}0.492 * * * \\
(0.103)\end{array}$ \\
\hline Adjusted $\mathrm{R}^{2}$ & 0.71 & 0.32 & 0.47 & 0.48 & 0.59 \\
\hline F-statistic & 56.6 & 12.9 & 19.2 & 35.7 & 47.4 \\
\hline \multicolumn{6}{|c|}{ 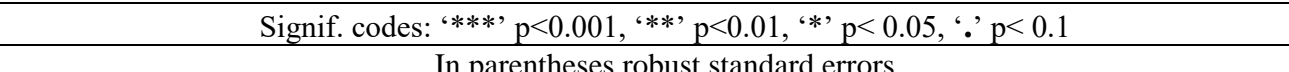 } \\
\hline
\end{tabular}

\footnotetext{
${ }^{10}$ The only exceptions from the 25 countries in the MR group are Kuwait, Qatar and Saudi Arabia
} 
Although we know from previous studies that factors such as human capital (Bresnahan et al., 2002) and availability of telecommunications infrastructure (Shih et al., 2007; Dedrick et al., 2013) are expected to have a positive effect on productivity gains from ICT investments, this effect does not stand out in the ICT elasticity of the high ranking group of countries. From a policy making point of view we would be skeptical whether investing heavily and taking the lead in the telecommunications infrastructure and services at the national level will reap more gains from ICT investments. This remark, however, takes into consideration only the economic point of view and does not belittle the multifaceted impact of ICT in the political, social and environmental areas as pointed out in the introduction.

\section{Conclusion}

The majority of the literature in this research field is carried out by comparing ICT output elasticities from developed and developing/emerging countries, with the categorization criterion being the GDP per capita. The main goal of the paper is to investigate whether electronically developed countries in terms of human capital, telecommunications infrastructure and online services are able to gain excessive returns from ICT investments. In that respect the purpose is twofold. First of all, to determine whether the well-understood benefits of information quality, cost reduction in administrative processes, better training capabilities and better inclusion of citizens in digital services can boost the returns from ICT investments as a measure of better ICT usage. Secondly, to serve as a measure of robustness of previous works by proposing a different criterion of country sample selection from GDP per capita. This assertion is valid since the majority of the countries in the MR group are also emerging or developing ones.

Our findings reveal that both electronically developed countries and countries that lag behind according to UN's EGDI ranking exhibit a positive and significant relationship between ICT investments and economic growth. The difference in the output elasticities of the two groups of countries is rather small, whereas the hypothesis test of equality of coefficients could not be rejected. Therefore, we can confirm that contrary to early studies in the field, the effect of ICT investments in economic growth of emerging/developing countries is statistically significant. This remark is in line with the recent literature, but it differs with respect to the ICT elasticity of electronically developed countries being lower than the one of emerging/developing countries. Finally, we did not find econometric evidence to support the hypothesis of electronically developed countries gaining more from ICT investments from an economic point of view.

\section{References}

Bresnahan, T.F., Brynjolfsson, E. and Hitt, L.M., (2002). Information technology, workplace organization, and the demand for skilled labor: Firm-level evidence. The Quarterly Journal of Economics, 117(1), 339-376. https://doi.org/10.1162/003355302753399526

Cardona, M., Kretschmer, T. and Strobel, T. (2013). ICT and productivity: conclusions from the empirical literature. Elsevier, Information Economics and Policy, 25(3), 109-125.

https://doi.org/10.1016/j.infoecopol.2012.12.002

Dedrick, J., Kraemer, K. L., and Shih, E. (2013). Information technology and productivity in developed and developing countries. Journal of Management Information Systems, 30(1), 97-122. https://doi.org/10.2753/MIS0742-1222300103

Dewan, S., \& Kraemer, K. L. (2000). Information technology and productivity: Evidence from country-level data. Management Science, 46(4), 548-562.

https://doi.org/10.1287/mnsc.46.4.548.12057 
Dimelis, S., \& Papaioannou, S. (2010). FDI and ICT effects on productivity growth: A comparative analysis of developing and developed countries. European Journal of Development Research, 22(1), 79-96. https://doi.org/10.1057/ejdr.2009.45

Draca, M., Sadun, R. and Van Reenen, J. (2006). Productivity and ICT: A Review of the Evidence. CEP Discussion Paper, No 749. http://eprints.lse.ac.uk/id/eprint/4561

Kneller, R. (2005). Frontier technology, absorptive capacity and distance. Oxford Bulletin of Economics and Statistics, 67(1),1-23.

https://doi.org/10.1111/j.1468-0084.2005.00107.x

Lee, S.Y.T., Gholami, R. and Tong, T.Y., (2005). Time series analysis in the assessment of ICT impact at the aggregate level-lessons and implications for the new economy. Elsevier, Information \& Management, 42(7), 1009-1022. https://doi.org/10.1016/j.im.2004.11.005

Millo, G., (2017). Robust standard error estimators for panel models: a unifying approach. Journal of Statistical Software, 83(3). https://mpra.ub.uni-muenchen.de/54954/

Niebel, T. (2018). ICT and economic growth-Comparing developing, emerging and developed countries.Elsevier, World Development, 104, 197-211. https://doi.org/10.1016/j.worlddev.2017.11.024

Organisation for Economic Co-operation and Development (OECD), (2009). Measuring Capital - OECD Manual 2009, 2nd ed. Paris, France. OECD Publishing. https://www.oecd.org/sdd/productivity-stats/43734711.pdf

Pohjola, M. (2002). The new economy in growth and development. Oxford Review of Economic Policy, 18(3), 380-396. https://doi.org/10.1093/oxrep/18.3.380

Shih, E., Kraemer, K.L. and Dedrick, J., (2007). Research note-determinants of countrylevel investment in information technology. Management science, 53(3), 521-528. https://doi.org/10.1287/mnsc. 1060.0670

Steinmueller, W. E. (2001). ICTs and the possibilities for leapfrogging by developing countries. International Labour Review, 140(2), 193-210. https://doi.org/10.1111/j.1564913X.2001.tb00220.x

Stiroh, K.J. (2005). Reassessing the impact of IT in the production function: A meta-analysis and sensitivity tests. Annales d'Economie et de Statistique, 79/80, 529-561. https://www.jstor.org/stable/20777587

UN (2019). Electronic Government Development Index. Available: https://publicadministration.un.org/egovkb/en-us/Data-Center

Wooldridge, J.M., (2015). Introductory econometrics: A modern approach. Nelson Education Toronto, Canada:

Yousefi, A. (2011). The impact of information and communication technology on economic growth: Evidence from developed and developing countries. Economics of Innovation and New Technology, 20(6), 581-596. https://doi.org/10.1080/10438 599.2010.544470 